\section{Kastamonu Eğitim Dergisi Kastamonu Education Journal}

Mayıs 2019 Cilt:27 Sayı:3

kefdergi.kastamonu.edu.tr
Başvuru Tarihi/Received: 17.01.2018

Kabul Tarihi/Accepted: 30.05.2018

DOI: $10.24106 /$ kefdergi. 2575

\title{
Öğretmenlerin Pozitif Psikolojik Sermayelerinin Çalışmaya Tutkunlukları Üzerine Etkisi
}

\section{The Effect of The Positive Psychological Capital of The Teachers on The Work Engagement}

\section{Öz}

\author{
Rasim TÖSTEN ${ }^{1}$, Hacı İsmail ARSLANTAŞ ${ }^{2}$, Gülay ŞAHIN ${ }^{3}$
}

Pozitif psikolojik sermaye, olumsuzluklara odaklanmak yerine bireyin iç dinamiklerini harekete geçirmeyi dolayısıyla içsel bir hareketle sürece yaklaşmayı amaçlayan bir yaklaşımdır. Çalışmaya tutkunluk ise "pozitif, tatmin edici, çalışmayla ilgili ruh hali" olarak tanımlanmaktadır. Her iki kavramın teorik temeli incelendiğinde pozitiflik durumunun olduğu görülmektedir. Bu çalışmada ise, öğretmenlerin pozitif psikolojik sermaye yeterlikleri ile çalışmaya tutkunlukları arasındaki ilişkinin ortaya konulması amaçlanmaktadır. Bu araştırma ilişkisel tarama modelinde olup nicel desenlidir. Araştırmanın çalışma grubunda 487 öğretmen araştırmaya dâhil edilmiştir. Araştırmada öğretmenlerin görüşlerini almak amacıyla iki ölçek kullanılmıştı. Öğretmenlerin Schaufeli ve diğerleri (2002) tarafindan geliştirilen Turgut (2011) tarafindan Türkçe'ye uyarlanan Çalışmaya Tutkunluk Ölçeği ve pozitif psikolojik sermayenin ölçümü için Çetin ve Basım (2012) tarafindan geliştirilen Pozitif Psikolojik Sermaye Ölçeği'dir. Araştırma sonucunda elde edilen 487 ölçekteki veriler betimsel (tanımlayıcı) istatistiksel teknikler (frekans, yüzde, aritmetik ortalama, standart sapma) ile değişkenler arası korelasyon ve basit regresyon analizleri kullanılmıştr. Analizlerde $p<.05$ düzeyi esas alınmıştır. Araştırma sonucunda pozitif psikolojik sermaye ile çalışmaya tutkunluk arasında yüksek düzeyde pozitif yönde bir ilişsi olduğu, pozitif psikolojik sermayenin bileşenlerinin tamamının çalışmaya tutkunluğu yordadığı görülmüştür.

Anahtar Kelimeler: psikolojik sermaye, çalışmaya tutkunluk, pozitif psikoloji

\section{Abstract}

Positive psychological capital is an approachment which aims to awaken individual's internal dynamics instead of focusing on negativity, and thereby, aims to approach to the process with an intrinsic movement. Work engagement is also defined as "positive, satisfying, mood which is related to work". When the theoretical bases of both are examined, it is discovered that they both include positivity. In this study, it is aimed to put forward the relation between teachers' competency of positive psychological capital and their work engagements. This study is conducted in a model of relational screening and has a quantitative characteristic. As the working group of study, 487 teachers have been included in the research. In order to gather teachers' opinions, two scales have been used. One of them is "The Scale of Work Engagement" developed by Schaufeli et al. (2002) and adapted to Turkish by Turgut (2011) and the other is "The Scale of Positive Psychological Capital" developed by Çetin and Basım (2012). Descriptive (definitive), statistical techniques (frequency, percentage, arithmetic average, standard deviation) and the correlation between variables and also simple regression analyses are used for analyzing the data obtained as a result of the research. The level of $p<.05$ is taken as base under analyses. In consequence of the study, it is discovered that there is a high positive relationship between positive psychological capital and work engagement and all of the components of positive psychological capital predict work engagement.

Keywords: psychological capital, work engagement, positive psychology

1. Siirt Üniversitesi, BESYO,Siirt, Türkiye; https://orcid.org/0000-0001-5135-7286

2. Mersin Üniversitesi, Eğitim Fakültesi, Mersin, Türkiye; https://orcid.org/0000-0001-2345-6789

3. Siirt Milli Eğitim Müdürlüğü, Siirt, Türkiye; https://orcid.org/0000-0003-2070-9837..

Atıf / Citation: Tösten, R., Arslantaş, H.İ., ve Şahin, G. (2019). Öğretmenlerin pozitif psikolojik sermayelerinin çalışmaya tutkunlukları üzerine etkisi.Kastamonu Education Journal, 27(3), 1073-1079. doi:10.24106/kefdergi.2575 


\section{Introduction}

After Second World War, psychology has started to focus on positive aspects of human behaviours and begun to be seen as a curative science (Seligman and Csikszentmihalyi, 2000). Positive psychological capital, according to this context, is an approachment that aims to awaken internal dynamics of individuals instead of focusing on negativity. When we examine the effects of psychological capital, we see that it is influential on some organizational behaviours of employees such as productivity, job satisfaction, emotional labour and organizational citizenship (Tösten and Özgan, 2014). Researchers, in recent years, have gained a new perspective through positive aspects of psychological capital. Since the competency on psychological capital could be strengthened, the importance of these kinds of researches rises (Tösten, 2015). When we look into the studies regarding teachers' problems in Turkey, it is understood that teachers in Turkey are very reluctant, their commitment levels are low and job burnout levels quite high. Therefore, this situation may be explained by their work engagements (Schaufeli and Bakker, 2003; Ashforth and Humphrey, 1995). While new teachers who are freshly appointed to their duties are very aspirant, but through professional seniority, their idealistic aspirations are getting weaken and their negative thoughts on that "the current system will continue with all its faults and never change" prevail (Ergül, Saygın, and Tösten, 2014). It is considered that the components such as optimism, hope, resilience, self-efficacy and work engagement will be influential on their getting rid of these negative attitudes. It is thought that, at this point, positive psychologic capital and work engagement meet up in a positive manner, so they are two significant concepts which are explaining each other. Although the relationship between positive psychological capital and work engagement has already been examined for some other organizations, studies are very limited when it comes to educational organizations. Therefore, this study is considered as substantial also from this perspective.

\section{Positive Psychological Capital}

Types of human capital which are featuring human factors in the competition are becoming important increasingly (Luthans and Youssef, 2004). While psychological studies generally have been focused on negative aspects of human behaviours such as failure, pathology, burnout, and desperation; the positive psychology trend especially lays emphasis on some issues about having a happy life (Caprara and Cervore, 2003). When we look at the studies on positive psychological capital, it is observed that the people who have high levels of psychological capital are also advantageous in some situations such as job satisfaction (Akçay, 2012), problem solving ability, motivation and success. There is another subject needs to be mentioned that the psychological capital's being open to be developed is an important start point for enhancing so many other factors (Luthans, Youssef and Avolio, 2007; Çetin and Basım, 2012; Luthans, 2002).

Psychological capital is a whole of some other components. Although there are 4 basic components (self-efficacy, hope, optimism and psychological resilience), this number can be augmented. Some other components such as satisfaction, self-report, extroversion, inner conscience, delightfulness, neuroticism, openness, self-esteem, self-consciousness, trust, pertinacity, discipline, and attachment are also being examined under the context of positive psychological capital (Luthans and Avolio, Avey, Norman, 2007; Luthans, 2002; Luthans, Vvogelgesang, Lester, 2006; Luthans, Youssef, 2004).

In Turkey, regarding issues of psychological capital, some significant studies have led to others in the country. These are: the study named as "The impact of psychological capital on organizational citizenship behaviour: A field study" conducted by Berberoğlu (2013); the study named as "The Effects of Positive Psychological Capital on Job Satisfaction in the Context of Personal Values and A Research" conducted by Akçay (2012); the study named as "The Relationship between Positive Psychological Capital and Organizational Commitment" conducted by Çınar (2011); "The Role of Work Family Spillover and Psychological Well-Being on the Effect of Psychological Capital on Performance" conducted by Polatcl (2011); the study named as "A Model Proposed to Determine the Effects of Career Planning on the Relation Between Psychological Capital and Occupational Commitment" conducted by Kaya (2012); and finally the study named as "The Conditional Variable Roles of Psychological Capital and Perceived Organizational Justice in the Relationship between Communication and Resistance to Change bywhich Trust to Organization" conducted by Saruhan (2013) again and Tösten's study named as "Examination of Teachers' Perceptions on Positive Psychological Capital".

\section{Work Engagement}

In today's business life, negative thoughts such as working environment, stress, job burnout, mobbing and employee turn over are being handled more than positive concepts such as happiness, hope, peace, organizational commitment, and work engagement. However, in recent times, through positivity momentum occurred in the field of psychology, some affirmative considerations such as work engagement have begun to draw attention and the studies regarding those considerations have gradually increased (Schaufeli and Bakker, 2004). The word of "engagement" is de- 
rived from the root of "engage". The word "engage", in its original meaning, is defined as holding in pledge something or someone or giving a promise. But today, it means that to be preoccupied with an activity or to be got involved in. In Turkish literature, the term of "work engagement" is translated to this language with different expressions by different researchers. These are commitment to work (Eryılmaz and Doğan, 2012), organizational engagement (Esen, 2011), the commitment to work from the heart (Çakıl, 2011), integration with work (Ardıç and Polatçı, 2009) and addiction to work (Metin, 2010).

Work engagement is described as employees' devoting themelves wholely to meet the roles of their occupations in physical, cognitive and emotional manners (Kahn, 1990). Among these three factors, the physical component is explained as "one's spending his/her whole energy when working"; the emotional component as "one's setting her/his heart on"; and the cognitive component as "one's becoming wholly absorbed in work and forgetting everything" (Ashforth and Humphrey, 1995).

Work engagement is accepted as the opposite of burnout. In contrast to burnout, employees who are engaged in their works are very energetic individuals, those people of who think they can meet all expectations and required responsibilities easily and who love their jobs. However, it is not possible to say that the individuals who do not feel burnout are all engaged to their works. For this reason, work engagement and burnout should be evaluated independently (Schaufeli and Bakker, 2003: 4).

When employees' work engagement or burnout increases, their job satisfaction also will be affected by directly. Job satisfaction is in relation with several demographical, psychological and institutional variables. Being young, being under educated and amount of income are in among such factors reducing job satisfaction. While work engagement level of employees having job satisfaction increases, their burnout level decreases (Alanyall, 2006). Therefore, it can be stated that the work engagement directly affects organizational behaviours.

\section{The Relationship of Work Engagement with Similar Concepts}

The approaches related to engagement are described with different in concepts. First, the concept of "employee engagement" delivered by Kahn, after that, the concept of "job engagement" by Maslach and Leiter, and lastly, the concept of "work engagement" by Schaufeli et al. are presented to the literature. It would be beneficial to explain these similar concepts here.

Employee Engagement. First researchers conducting studies on the concept of employee engagement were Schneider, Macey, Barbera and Young. These researchers have described employee engagement as employees' being energetic while working, enjoyed and productive (Schneider, 2012). Another definition is made under a study which was conducted jointly by researchers of Gallup Consultation Firm and academicians. According to this definition, employee engagement is feeling committed to the work, being satisfied and being a part of that organization willingly. This study also revealed the employee engagement-performance relationship which had not been measured until that time (Harter et al., 2002).

Job Engagement. Job engagement is described as an individual's being energetic in conformity with the dynamism necessary for that job. Moreover, in the same study, it is stated that job engagement has not been examined adequately in terms of personality characteristics and situational factors, so much more studies haveto be conducted on this issue (Inceoğlu, Warr, 2011). Job engagement is defined also by Roberts and Davenport as feeling emotions of enthusiasm and ambition while working and concentrating on that work. When an individual engages truly with her/ his job, s/he defines her/himself with that job and gets satisfaction from that by working with motivation (Roberts and Davenport, 2002). Positive working relationships and strong organizational culture promote job engagement, while reducing burnout (Hernandez, et al., 2014). To employ those individuals who have job engagement, the managers must pay sufficient importance to loyalty, sharing the vision, encouragement for participation in decisions, authorization and rewarding (Hodgetts, 1997).

\section{The Purpose of the Study}

In this study, it is aimed to find out the relationship between teachers' competencies on positive psychological capital and their work engagements. For reaching the study's basic goal, answers to questions presented below will be sought.

1. What are the levels of positive psychological capital and work engagement of teachers?

2. Is there a relationship between teachers' positive psychological capital and work engagement levels? 
3. Does positive psychological capital of teachers affect their work engagement levels?

\section{Method}

This study has a quantitative characteristic but it is conducted in relational screening model. The relationship screening model covers the studies which aim to determine relations between two or more variables and to obtain clues on cause and effect relations (Büyüköztürk et al., 2014).

\section{Population and Sample}

The population of the study is composed of 7843 teachers who are working in elementary schools, secondary schools and high schools of Batman city center. In this framework, the sample of the study consists 487 teachers who have worked during the 2015-2016 school year in Batman city center. To compose the sample representing the population, the scales have been distributed to 500 teachers in total with the method of random. And 487 of the scales were processed under the study.

Table 1. Personal Information of Teachers Participating to the Study

\begin{tabular}{lcclcclcc}
\hline Marital Status & $\mathrm{N}$ & $\%$ & Educational Status & $\mathrm{N}$ & $\%$ & Sex & $\mathrm{N}$ & $\%$ \\
\hline Married & 319 & 65.5 & Bachelor's Degree & 415 & 85.2 & Female & 280 & 57.5 \\
Singular & 168 & 34.5 & Master's Degree & 72 & 14.8 & Male & 207 & 42.5 \\
Total & 487 & 100.0 & Total & 487 & 100.0 & Total & 487 & 100.0 \\
\hline
\end{tabular}

According to the marital status of teachers participated, $65.5 \%$ of them are married ( $\mathrm{N}: 319)$ and $34.5 \%$ are singular. According to educational status, $85.2 \%$ of them have bachelor's degree ( $\mathrm{N}: 415)$ and $14.8 \%$ have master's degree. It is noteworthy that most of the teachers have bachelor's degree $(85.2 \% ; \mathrm{N}: 415)$. According to sex information, $57.5 \%$ of them are female ( $\mathrm{N}: 280)$ and $42.5 \%$ are male $(\mathrm{N}: 207)$.

\section{Data Collection Tool}

In the study, two scales have been used to collect opinions of teachers. These are; "The Scale of Positive Psychological Capital" adapted to Turkish by Çetin and Basım (2012) for measuring psychological capital of teachers, and "The Scale of Work Engagement", adapted to Turkish by Turgut (2011), for measuring teacher's work engagement.

In order to measure positive psychological capital of teachers, "The Scale of Psychological Capital" having 24 items which was developed by Luthans et al. (2007) and adapted to Turkish by Çetin and Basım (2012), was used. The scale has four dimensions: Self-efficacy, Hope, Optimism and Resilience. Each subscale consists of six items. The scale is designed in the form of 5-point Likert-typed. This pointsare; from left to right, "1-Strongly Disagree", "2-Disagree", "3-Neutral", "4- Agree" and "5-Strongly Agree". The validation of the scale was made by Çetin and Basım (2012). Cronbach's Alpha internal consistency is found as ,69. Under the studies conducted in the field of social sciences, values between $0.60 \leq \alpha<0.80$ are accepted as quite reliable and values between $0.80 \leq \alpha<1.00$ accepted as highly reliable (Can, 2014).

"The Scale of Work Engagement" developed by Schaufeli et al. (2002) and adapted to Turkish by Turgut (2011) is consists of 3 dimensions and 17 items in total. 6 of 17 items measure "vigor" dimension, 5 items measure "dedication" dimension and 6 items measure "absorption" dimension. The version adapted to Turkish is 5 Likert and ranked as from left to right, "Never", "Rarely", "Sometimes", "Very Often" and "Always".

\section{Data Collection and Analyses}

The tool was applied to participants via reaching them directly. 487 of 500 data was processed. For analyzing the data gathered, descriptive (definitive), statistical (frequency, arithmetic average, standard deviation) and the correlation between variables and simple regression analyses were being used. The level of $p<.05$ is taken as a base under analyses.

\section{Findings and Interpretation}

Under this chapter of the study, teachers' psychological capital and theirlevels of work engagement are measured, the relationship between them is expressed and the findings revealing whether their perceptions on psychological capital affects the work engagement or not are interpreted via tables. 
Table 2. Descriptive Statistics onTeachers' Perceptions on Psychological Capital and Work Engagement

\begin{tabular}{llccc}
\hline Scales & Dimensions & $\mathrm{N}$ & $\mathrm{X}$ & $\mathrm{ss}$ \\
\hline \multirow{4}{*}{ Work Engagement } & Vigor & 487 & 3.61 & .89 \\
& Dedication & 487 & 3.89 & .84 \\
& Absorption & 487 & 3.46 & .87 \\
& Total & 487 & 3.66 & .79 \\
\hline \multirow{5}{*}{ Psychological Capital } & Optimism & 487 & 3.69 & .85 \\
& Resilience & 487 & 3.68 & 1.15 \\
& Hope & 487 & 3.72 & .91 \\
& Self-Efficacy & 487 & 3.90 & .86 \\
& Total & 487 & 3.76 & .86 \\
\hline
\end{tabular}

It is observed that teachers' level of work engagement is high $(X=3.66)$. Sub-dimensions of the scale; "vigor dimension $(X=3.61)$ " and "dedication dimension ( $X=3.89)$ " are in high-levels but "absorption dimension $(X=3.46)$ " is in medium-level. On the other hand, it is observed that the competency levels on psychological capital of teachers participating to the study are high $(X=3.76)$. Sub-dimensions of the Scale of Psychological Capital are calculated as "self-efficacy $(X=3.90)$ ", "optimism $(X=3.69)$ ", "psychological resilience $(X=3.68)$ " and "hope (3.72)".

Table 3. The Relationship between Teachers' Psychological Capital and Work Engagement

\begin{tabular}{ccc}
\hline Variables & & Work Engagement \\
\hline & $\mathrm{r}$ & $.791^{* *}$ \\
Psychological Capital & $\mathrm{p}$ & .000 \\
& $\mathrm{~N}$ & 487 \\
\hline
\end{tabular}

When the relation between teachers' positive psychological capital and their work engagement is examined, it is understood that there is the positively high level of relation ( $r=.79 ; p<.05)$. From this framework, it could be said that teachers' work engagement levels will increase as long as their competencies on the psychological capital increase.

Table 4. The Results of Regression Analysis on the Effects of Teachers' Psychological Capitals on Their Work Engagement Levels

\begin{tabular}{llllll}
\hline Predictive Variables & $\mathrm{R}$ & $\mathrm{R}^{2}$ & $\beta$ & $\mathrm{t}$ & $\mathrm{p}$ \\
\hline Optimism & .69 & .47 & .69 & 20.81 & .00 \\
Resilience & .76 & .58 & .76 & 25.73 & .00 \\
Hope & .76 & .58 & .76 & 26.08 & .00 \\
Self-Efficacy & .66 & .44 & .66 & 19.58 & .00 \\
Psychological Capital in Total & .79 & .63 & .79 & 28.49 & .00 \\
\hline $\mathrm{p} \leq .01^{*}$ & & & & &
\end{tabular}

Generally, it is understood that teachers explained their positive psychological capital work engagement as $63 \%$ and the variables included into the model to predict work engagement made the significant contribution to the model $(p<0.01)$. Besides, it is observed that the most effective variable of predictive variables is "hope" and influences in a positive way $(\beta=.76 ; \mathrm{R} 2=.58 ; \mathrm{p} \leq .05)$.

\section{Conclusion and Discussion}

As a result of the study, it is discovered that teachers' competencies on positive psychological capital and work engagements are in high levels. Having high levels of competencies on positive psychological capital is an advantageous situation for organizations. When the impact areas of the psychological capital are examined, it could be seen that it makes positive contributions to organizational behaviours. Psychological capital has impacts in explaining so many factors such as organizational climate (Luthans et al., 2008), burnout (Tösten et al., 2014), emotions (Avey et al., 2008), employee's attitudes towards to work (Larson and Luthans, 2006). Likewise, employees' having high levels of work engagement is also desired by organizations. It is expected from individuals who have high levels of work engagement to have lower levels of burnout (Hakanen, Bakker and Schaufeli, 2006; González-Romá et al., 2006), to be strong and energetic (Bakker and Demerouti, 2008) and to have high levels of organizational commitment (Hallberg and Schaufeli, 2006; Hakanen et al., 2008). Therefore, it could be said that positive psychological capital and work engagement 
both make positive contributions to organizational behaviours and this situation is advantageous also for educational organizations.

In employees' working lives, positive psychological capital and work engagement are both important. Positivity lies behind both of them and they are issues affecting organizational behaviours (Sweetman and Luthans, 2010; Tösten and Özgan, 2014; Tösten, 2015;). Considering the theoretical infrastructure, it is expected both of them to be interrelated. According to Waal and Pienaar's study (2013), hope, optimism, and self-efficacy are influential in explaining work engagement. When we look into research investigating the relationship between work engagement and psychological capital, it could be seen that there is the significant relationship in some groups other than educational organizations (Nigah, Davis and Hurrell, 2012; Bhatnagar, 2012; Simons and Buitendach, 2013). It is realized that studies investigating what would be the results of this relationship when it comes to educational organizations are quite limited. As a result of this study, it is found that there is a positive relationship between psychological capital and work engagement in educational organizations, too. Moreover, positive psychological capital declares work engagement as $58 \%$.

\section{Bibliography}

Akçay, H. V. (2012). Pozitif Psikolojik Sermayenin İş Tatmini İle İlişkisi. Kahramanmaraş Sütçü Imam Üniversitesi İktisadi ve Idari Bilimler Fakültesi Dergisi. 2(1). 123-140

Alanyalı, L. K. (2006). Örgütsel Stres Kaynaklarının iş Tatminine Olan Etkilerinin Tükenmişlik ve Dinçlik (Coşku) Etkileri Bağlamında Incelenmesi. Yayımlanmamış Yüksek Lisans Tezi. Uludağ Üniversitesi Sosyal Bilimler Enstitüsü. Bursa

Ardıç, K and Polatçı, S. (2009). Burnout Syndrome and the Other Side of Medallion: Engagement. Erciyes University Faculty of Economics and Administrative Sciences, 32, pp. 21-46.

Ashforth, B. H. (1995). Emotion in the workplace: A reappraisal. Human Relations. 48, 97-125.

Avey, J. B., Wernsing, T. S., \& Luthans, F. (2008). Can positive employees help positive organizational change? Impact of psychological capital and emotions on relevant attitudes and behaviors. The Journal of Applied Behavioral Science, 44(1), 48-70.

Bakker, A. B., \&Demerouti, E. (2008). Towards a model of work engagement. Career Development International, 13(3), 209-223.

Berberoğlu, N. (2013). Psikolojik sermayenin örgütsel vatandaşlık davranışı üzerine etkisi: Bir alan araştırması. (Yayımlanmamış yüksek lisans tezi). Gazi Üniversitesi, Sosyal Bilimler Enstitüsü, İşletme ABD

Bhatnagar, J. (2012). Management of innovation: Role of psychological empowerment, work engagement and turnover intention in the Indian context. The International Journal of Human Resource Management, 23(5), 928-951.

Büyüköztürk, Ş., Çakmak, E., Akgün, Ö.E. Karadeniz, Ş., Demirel, F. (2014). Bilimsel Araştırma Yöntemleri. Ankara: Pegem A Yayıncılık.

Caprara, G. V., \& Cervone, D. (2003). A Conception of Personality for a Psychology of Human Strengths: Personality as an Agentic. Self Regulating System.: L. G.

Çetin, F., \& Basım, H.N. (2012). Organizational psychological capital: A scale adaptation study. Public Administration Journal, $45(1), 121-137$.

Çınar, E. (2011). Pozitif psikolojik sermayenin örgütsel bağıııkla ilişkisi. (Yayımlanmamış yükseklisans tezi). Dokuz Eylül Üniversitesi, Sosyal Bilimler Enstitüsü İşletme ABD, İzmir

De Waal, J. J., \& Pienaar, J. (2013). Towards understanding causality between work engagement and psychological capital. SA Journal of Industrial Psychology, 39(2), 1-10.

Ergül, H. F., Saygın, S., \& Tösten, R. (2013).Sınıf Öğretmenlerinin Tükenmişlik Düzeylerinin Çeşitli Değişkenler Açısından İncelenmesi. Elektronik Dicle Üniversitesi Sosyal Bilimler Enstitüsü Dergisi. 5(10).

Esen, E. (2011). Çalışanların Örgüte Cezbolması. Marmara Üniversitesi iiBF Dergisi, 30(1), 377-390.

González-Romá, V., Schaufeli, W. B., Bakker, A. B., \&Lloret, S. (2006). Burnout and work engagement: Independent factors or opposite poles?.Journal of Vocational Behavior, 68(1), 165-174.

Hakanen, J. J., Bakker, A. B., \&Schaufeli, W. B. (2006). Burnout and work engagement among teachers. Journal of School Psychology, 43(6), 495-513.

Hakanen, J.J., Schaufeli, W.B., \& Ahola, K. (2008). The Job demands-resources model: A three-year cross-lagged study of burnout, depression, commitment, and work engagement. Work \& Stress, 22(3), 224-241.

Hallberg, U. E., \&Schaufeli, W. B. (2006). "Same same” but different? Can work engagement be discriminated from job involvement and organizational commitment?. European Psychologist, 11(2), 119-127.

Harter, J. K.,Schmidt, F. L., Hayes, T. L., (2002). Business-unit-level relationship between employee satisfaction, employee engagement, and business outcomes: A meta-analysis, Journal of Applied Psychology, 87(2), p. 269.

Hernandez, B.,Stanley, B., Miller, L. (2014). Job embeddedness and job engagement: Recommendations for a supportive social work environment. Human Service Organizations Management, Leadership \& Governance, 38 (4), p. 342.

Hodgetts, R. M. (1997). Yönetim: Teori, Süreç ve Uygulama, (Çev. Çetin, C., \& Mutlu, E. C.) 5. Baskı'dan Çeviri. İstanbul: Der Yayınları. s. $451-452$. Inceoğlu, I., \& Warr, P. (2011). Personality and Job Engagement., Journal of Personnel Psychology. 10(4) p. 177

|Kastamonu Eğitim Dergisi, 27(3), 2019| 
Kahn, W. (1990). Psychological conditions of personal engagement and disengagement at work. Academy of Management Journal, 33 (4), 692-724.

Kaya, Ş. D. (2012). Psikolojik sermaye ve mesleki bağllık ilişkisine kariyer planlamasının etkilerinin belirlenmesine yönelik bir model önerisi. Yayımlanmamış doktora tezi. Selçuk Üniversitesi Sosyal Bilimler Enstitüsü, İşletme ABD.

Larson, M., \&Luthans, F. (2006). Potential added value of psychological capital in predicting work attitudes. Journal of Leadership \& Organizational Studies, 13(1), 45-62.

Luthans, F., Youssef, C.M., Avolio, B.J. (2007). Psychological Capital. New York: Oxford University Press.

Luthans, F., Norman, S. M., Avolio, B. J., \&Avey, J. B. (2008). The mediating role of psychological capital in the supportive organizational climate employee performance relationship. Journal of Organizational Behavior, 29(2), 219-238.

Luthans, F., Avolio, B.J., Avey, J.B. and Norman, S.M. (2007). Positive psychological capital: Measurement and relationship with performance and satisfaction. Leadership Institute Faculty Publications, 60:541-572

Luthans, F. \& Youssef, C. M. (2004). Human, social and now positive psychological capital management: Investing in people for competitive advantage. Organizational Dynamics. 33:2, 143-160.

Luthans, F., Vogelgesang, G. R., \& Lester, P. B. (2006). Developing the psychological capital of resiliency. Human Resource Development Review, 5(1), 25-44..

Luthans, F. (2002). Positive organizational behavior: Developing and managing psychological strengths. The Academy of Management Executive, 16(1), 57-72.

Nigah, N., Davis, A.J., \& Hurrell, S.A. (2012). The impact of buddying on psychological capital and work engagement: an empirical study of socialization in the professional services sector. Thunderbird International Business Review, 54(6), 891-905.

Polatcl, S. (2011). The Role of Work Family Spillover and Psychological Well-Being on the Effect of Psychological Capital on Performance (Unpublished Phd Thesis). Erciyes University Institution of Social Sciences, Department of Management.

Roberts, D., \& Davenport, T. (2002). Job Engagement: Why it's important and how to improve it. Employment Relations Today, 29 (3), 21-29.

Saruhan, N. (2013). iletişimin kuruma güven aracılığıla değişime direnç ile olan ilişkisinde psikolojik sermaye ve algılanan kurumsal adaletin şartlı değişken rolü. (Unpublished Phd Thesis). Marmara University, Institution of Social Sciences, Department of Management

Schaufeli, W. B., Salanova, M., González-Romá, V., \& Bakker, A. B. (2002). The Measurement of Engagement and Burnout: A Two Sample Confirmatory Factor Analytic Approach. Journal of Happiness Studies, 3(1) ss.71-92.

Schaufeli, W. B., \& Bakker, A. B. (2004). Job demands, job resources, and their relationship with burnout and engagement: A multi-sample study. Journal of organizational Behavior, 25(3), 293-315.

Seligman, M.E.P., \& M. Csikszentmihalyi (2000), Positive Psychology: An Introduction, American Psychologist, 55: 5-14.

Simons, J. C., \& Buitendach, J. H. (2013). Psychological capital, work engagement and organisational commitment amongst call centre employees in South Africa. SA Journal of Industrial Psychology, 39(2), 1-12.

Sweetman, D., \& Luthans, F. (2010). The power of positive psychology: Psychological capital and work engagement. Work engagement: $A$ handbook of essential theory and research, 54-68.

Tösten, R. (2015). Öğretmenlerin Pozitif Psikolojik Sermayelerine Ilişkin Algılarının Incelenmesi.. Yayımlanmamış Doktora Tezi. Gaziantep Üniversitesi Eğitim Bilimleri Enstitüsü

Tösten, R., \& Özgan, H. (2014). Psikolojik sermaye ölçeği: Geçerlik güvenirlik çalışması. EKEV Journal of the Academy, 59

Turgut, T. (2011). Çalışmaya Tutkunluk: İş Yükü, Esnek Çalışma Saatleri, Yönetici Desteği ve İş-Aile Çatişmasi Ile illişkileri. Atatürk Üniversitesi iktisadi ve Idari Bilimler Dergisi, 25(3-4). 